\title{
Genome Sequence Analysis of New Isolates of the Winona Strain of Plum pox virus and the First Definitive Evidence of Intrastrain Recombination Events
}

\author{
Delano James, Dan Sanderson, Aniko Varga, Anna Sheveleva, and Sergei Chirkov
}

First, second, and third authors: Centre for Plant Health-Sidney Laboratory, Canadian Food Inspection Agency, 8801 East Saanich Road, North Saanich, British Columbia, V8L 1H3, Canada; and fourth and fifth authors: Department of Virology, Biology Faculty, Lomonosov Moscow State University, Leninskie Gory MSU 1/12, Moscow, 119991, Russia.

Accepted for publication 6 December 2015.

\begin{abstract}
James, D., Sanderson, D., Varga, A., Sheveleva, A., and Chirkov, S. 2016. Genome sequence analysis of new isolates of the Winona strain of Plum pox virus and the first definitive evidence of intrastrain recombination events. Phytopathology 106:407-416.

Plum pox virus (PPV) is genetically diverse with nine different strains identified. Mutations, indel events, and interstrain recombination events are known to contribute to the genetic diversity of PPV. This is the first report of intrastrain recombination events that contribute to PPV's genetic diversity. Fourteen isolates of the PPV strain Winona (W) were analyzed including nine new strain W isolates sequenced completely in this study. Isolates of other strains of PPV with more than one isolate with the complete genome sequence available in GenBank were included also in this study for comparison and analysis. Five intrastrain recombination

events were detected among the PPV W isolates, one among PPV C strain isolates, and one among PPV M strain isolates. Four (29\%) of the PPV W isolates analyzed are recombinants; one of which (P2-1) is a mosaic, with three recombination events identified. A new interstrain recombinant event was identified between a strain $\mathrm{M}$ isolate and a strain Rec isolate, a known recombinant. In silico recombination studies and pairwise distance analyses of PPV strain D isolates indicate that a threshold of genetic diversity exists for the detectability of recombination events, in the range of approximately $0.78 \times 10^{-2}$ to $1.33 \times 10^{-2}$ mean pairwise distance. RDP4 analyses indicate that in the case of PPV Rec isolates there may be a recombinant breakpoint distinct from the obvious transition point of strain sequences. Evidence was obtained that indicates that the frequency of PPV recombination is underestimated, which may be true for other RNA viruses where low genetic diversity exists.
\end{abstract}

Plum pox virus (PPV) causes sharka or plum pox disease and is considered to be the most important virus infecting stone fruits (Prunus spp.) (Cambra et al. 2006; García et al. 2014), and has been listed as one of the top 10 viruses in molecular plant pathology (Scholthof et al. 2011). PPV is a member of the genus Potyvirus, family Potyviridae (Adams et al. 2011). The virus contains a positive-sense single-stranded RNA genome consisting of approximately 9.8 to $10 \mathrm{~kb}$, and is flanked by a virus-encoded protein covalently linked to the $5^{\prime}$ noncoding terminus, and a poly (A) tail at the 3' terminus (García et al. 1994).

PPV is genetically diverse with nine distinct strains of the virus identified; D, M, EA, C, Rec, W, T, CR, and An (James et al. 2013). Strains vary in their natural host range, pathogenicity, aphid transmissibility, and geographic distribution. There exists genetic and biological diversity within strains (Maejima et al. 2011; Mavrodieva et al. 2013; Myrta et al. 2001; Schneider et al. 2011; Theilmann et al. 2006), hence effective control and management of this damaging virus requires strain identification and understanding the genetic and biological diversity that exists within strains. The genetic diversity that exists between PPV strains has facilitated the development of nucleic acid-based assays (Hammond et al.1998; Szemes et al. 2001; Varga and James 2005; Wetzel et al. 1991) and protein/serology-based assays (Boscia et al. 1997; Cambra et al. 1994; Candresse et al. 1998) that allow strain identification.

Corresponding author: D. James; E-mail address: Delano.James@inspection.gc.ca

*The $\boldsymbol{e}$-Xtra logo stands for "electronic extra" and indicates that two supplementary tables are published online.

http://dx.doi.org/10.1094/PHYTO-09-15-0211-R

(C) 2016 The American Phytopathological Society
RNA viruses exist typically as genetically diverse populations (García-Arenal et al. 2001; Roossinck 2003), with high mutation rates (Drake and Holland 1999; Tromas and Elena 2010; Korboukh et al. 2014) that are driven by the frequency of ribonucleotide misincorporation by the viral RNA-dependent RNA polymerase (Korboukh et al. 2014). Recombination is another mechanism that contributes to the genetic diversity of RNA viruses (García-Arenal et al. 2001; Roossinck 1997). Of the nine recognized PPV strains (James et al. 2013), at least two strains (Rec and T) are products of recombination events (Glasa et al. 2004; Serçe et al. 2009).

Recombination plays an important role in the evolution of potyviruses (Chare and Holmes, 2006), but their evolution is still not understood clearly and the relative significance of mutational changes compared with recombination events is unknown (Ohshima et al. 2007). Tromas et al. (2014) described observing relatively high recombination rates that was similar to high mutation rates in an in vivo study of the potyvirus Tobacco etch virus (TEV), and suggested that both mechanisms may have a similar impact on the genetic diversity of TEV. Although PPV strain Rec, characterized by a single recombination event, is widely distributed (Glasa et al. 2004) only a few actual recombination events have been identified in PPV, and these have been confined to interstrain recombination events (Cervera et al. 1993; Glasa et al. 2004, 2011; Myrta et al. 2006; Serçe et al. 2009). It is quite possible that the role and importance of recombination as a mechanism for PPV evolution has been overlooked or underestimated, since a threshold of genetic variation between contributing parents is essential for recombination event detection (Salminen 2003). Isolates that comprise most strains of PPV are relatively homogenous with low levels of diversity at different regions of their genomes (Glasa et al. 2011; Matic et al. 2011; Sheveleva et al. 2012a). PPV strain W appears to 
be comprised of the most genetically diverse group of isolates of any PPV strain (Glasa et al. 2011; Sheveleva et al. 2012a) and in this study was considered a suitable target for analysis to identify the possible existence of intrastrain recombination events.

Initially 8 genetically diverse PPV W isolates were selected for sequencing of their complete genomes. However, P2 was a mixed infection of 2 isolates (P2-1 and P2-2) bringing the total to nine new PPV W isolates. Isolates were selected to capture as wide a range of genetic diversity of PPV W as possible (Sheveleva et al. 2012b). These isolates all originated from Russia where frequent occurrence of strain W isolates has been described (Sheveleva et al. 2012a). Isolates naturally infecting several different hosts were included, and total RNA was extracted directly from the original infected Prunus hosts (Table 1) (Sheveleva et al. 2012b). PPV W isolates with sequences of their complete genomes deposited in GenBank were included in the final analysis. Isolates of other PPV strains with more than one isolate with the complete genome sequences available in GenBank were included also for comparison and analysis. Definitive evidence was obtained for the first time ever of intrastrain recombination in PPV, and evidence that recombination plays an important role in PPV evolution. Also, evidence was obtained to support the concept described by Salminen (2003) that a threshold of genetic diversity is essential for recombination detection.

\section{MATERIALS AND METHODS}

Total RNA extractions. Total RNA was extracted from all plant samples using Qiagen's RNeasy Plant Mini Kit, following the supplier's (Qiagen, Chatsworth, CA) instructions. Extractions were carried out at Lomonosov Moscow State University, Russia. The RNeasy spin columns were then shipped to the Centre for Plant Health-Sidney Laboratory, Canadian Food Inspection Agency, Canada, where the final elution of total RNA was carried out using nucleasefree water.
Complementary (c)DNA production, cloning, and sequencing. Primer design (Supplementary Table S1 provides primers) was aided by Clone Manager 9 (Professional Edition (c) 1994-2010, Scientific and Educational Software, Cary, NC) analysis of alignments of the complete sequences of PPV W isolates; W3174 (AY912055), LV-145bt (HQ670748), LV-141pl (HQ670746), and UKR44189 (JN596110). cDNA was generated from the total RNA eluates using Invitrogen's SuperScript II reverse transcription and the appropriate oligonucleotide primers (denaturation phase $5 \mathrm{~min}$ at $75^{\circ} \mathrm{C}$; synthesis phase $1 \mathrm{~h}$ at $42^{\circ} \mathrm{C}$ ). This was followed by touchdown PCR performed on the cDNA template using Invitrogen Platinum Taq DNA Polymerase High Fidelity. Plasmids with virusderived cDNA inserts were sequenced at the Nucleic Acid Protein Service Unit, UBC (Vancouver, BC), on an Applied Biosystems 3730 DNA Analyzer. For each assembly region, bidirectional sequencing was employed for at least three unique plasmid preps whose insert sequences overlapped adjacent assembly regions.

Genome assembly and sequence analysis. A consensus sequence of the virus genome was assembled from multiple trace files using Clone Manager 9, and the 'merger' feature of EMBOSS (http:// www.bioinformatics.nl/emboss-explorer/) as a supplementary tool. Accessions of PPV W sequenced previously were obtained through GenBank (www.ncbi.nlm.nih.gov). Alignments and neighbor-joining phylogenetic distances were generated in Clustal X 2.1 (Larkin et al. 2007; Thompson et al. 1997). Phylogenetic analysis was carried out using the neighbor-joining method described by Saitou and Nei (1987) within Clustal X, with the potyvirus Japanese yam mosaic virus (JYMV, accession number NC_000947) used as an outgroup. Bootstrap resamplings were set at 1,000 replicates, and tree figures were created in NJ Plot version 2.3 (Perrière and Gouy 1996). The SplitsTree 4.13 program developed by Huson and Bryant (2006), located at http://www.splitstree.org/, was used to provide a network view of the genome alignment data (exported from Clustal in NEXUS format), using the default parameters (uncorrected $P$ ).

TABLE 1. Plum pox virus (PPV) strain W isolates with complete genome sequences available that were used for RDP4 analysis in this study

\begin{tabular}{|c|c|c|c|c|c|c|c|}
\hline Isolate & $\begin{array}{l}\text { PPV } \\
\text { strain }\end{array}$ & Geographical origin & Host plant species & $\begin{array}{l}\text { Genome } \\
\text { size }(n t)\end{array}$ & $\begin{array}{l}\text { RDP4 } \\
\text { signal }\end{array}$ & $\begin{array}{c}\text { Accession } \\
\text { number }\end{array}$ & $\begin{array}{l}\text { Original } \\
\text { reference }\end{array}$ \\
\hline $\mathrm{P} 2-1^{\mathrm{b}}$ & W & Northern Caucasus, Russia & Prunus domestica (plum) & 9,789 & Yes (3) & HG916860 & This study \\
\hline $\mathrm{P} 2-2^{\mathrm{b}}$ & W & Northern Caucasus, Russia & P. domestica (plum) & 9,789 & No & LN852400 & This study \\
\hline $\mathrm{P} 3^{\mathrm{b}}$ & $\mathrm{W}$ & Northern Caucasus, Russia & P. domestica (plum) & 9,786 & No & HG916861 & This study \\
\hline $\mathrm{PD} 2^{\mathrm{b}}$ & $\mathrm{W}$ & Moscow, Russia & P. spinosa (blackthorn) & 9,786 & Yes (1) & HG916859 & This study \\
\hline $\mathrm{RD}^{\mathrm{b}}$ & $\mathrm{W}$ & Moscow Region, Russia & P. tomentosa (downy cherry) & 9,789 & No & HG916856 & This study \\
\hline STNB1 & $\mathrm{W}$ & Moscow Region, Russia & P. domestica (plum) & 9,789 & No & HG916857 & This study \\
\hline STNB2 & $\mathrm{W}$ & Moscow Region, Russia & P. domestica (plum) & 9,789 & No & HG916858 & This study \\
\hline $1410-1^{b}$ & W & Moscow, Russia & P. nigra (Canadian plum) & 9,789 & Yes (1) & HG916863 & This study \\
\hline $1410-7$ & $\mathrm{~W}$ & Moscow, Russia & P. nigra (Canadian plum) & 9,789 & No & HG916862 & This study \\
\hline W3174 & W & Ontario, Canada & P. domestica (plum) & 9,788 & Yes (2) & AY912055 & James and Varga 2005 \\
\hline$L V-145 b t^{b}$ & $\mathrm{~W}$ & Pure, Latvia & P. spinosa (blackthorn) & 9,786 & No & HQ670748 & Glasa et al. 2011 \\
\hline LV-141pl ${ }^{b}$ & $\mathrm{~W}$ & Pure, Latvia & P. domestica (plum) & 9,789 & No & HQ670746 & Glasa et al. 2011 \\
\hline UKR44189c & $\mathrm{W}$ & Ukraine & P. spinosa (blackthorn) & 9,786 & No & JN596110 & Mavrodieva et al. 2013 \\
\hline $\mathrm{Pk}$ & $\mathrm{W}$ & Tver Region, Russia & P. domestica (plum) & 9,789 & No & KC347608 & Sheveleva et al. 2013 \\
\hline SoC & $\mathrm{C}$ & Kishinev, Moldova & P. cerasus L. (sour cherry) & 9,795 & No & AY184478 & Fanigliulo et al. 2003 \\
\hline SwC & $\mathrm{C}$ & Southern Italy & P. avium (sweet cherry) & 9,795 & No & Y09851 & Fanigliulo et al. 2003 \\
\hline Ru17-sc & $\mathrm{CR}$ & Samara, Russia & $P$. cerasus L. (sour cherry) & 9,792 & No & KC020124 & Glasa et al. 2013 \\
\hline Ru30-sc & $\mathrm{CR}$ & Samara, Russia & P. cerasus L. (sour cherry) & 9,792 & No & KC020126 & Glasa et al. 2013 \\
\hline Ru18-sc & $\mathrm{CR}$ & Samara, Russia & P. cerasus L. (sour cherry) & 9,792 & No & KC020125 & Glasa et al. 2013 \\
\hline PS & M & Čačak, Serbia & Prunus sp. & 9,786 & No & AJ243957 & Sáenz et al. 2000 \\
\hline GR0019 & M & Greece & Prunus sp. & 9,786 & No & FM955843 & $\mathrm{NA}^{\mathrm{d}}$ \\
\hline SK68 & M & Pölöske, Hungary & P. domestica (plum) & 9,786 & No & M92280 & Palkovics et al. 1993 \\
\hline Rec $\operatorname{Cdn} 10$ & $\operatorname{Rec}$ & Grimsby, Ontario, Canada & Prunus sp. & 9,786 & Yes (1) & HG964686 & James and Varga 2011 \\
\hline BOR-3 & Rec & Slovakia & P. armeniaca (apricot) & 9,786 & Yes (1) & AY028309 & Glasa et al. 2004 \\
\hline PENN1 & $\mathrm{D}$ & Pennsylvania, United States & $P$ persica $($ peach $)$ & 9,786 & No & AF401295 & Schneider et al. 2011 \\
\hline Vulcan & $\mathrm{D}$ & Ontario, Canada & $P$. persica (peach) & 9,786 & No & AY912057 & James and Varga 2005 \\
\hline Ou 1 & $\mathrm{D}$ & Ōme-shi, Tokyo, Japan & P. mume (Chinese plum) & 9,786 & No & AB545926 & Maejima et al. 2011 \\
\hline EA-2005 & EA & El-Amar, Egypt & Prunus sp. & 9,791 & No & AM157175 & Myrta et al. 2006 \\
\hline EA-2006 & EA & El-Amar, Egypt & P. armeniaca (apricot) & 9,791 & No & DQ431465 & Glasa et al. 2006 \\
\hline
\end{tabular}

a Recombination detection program (RDP4) suite (Martin et al. 2010). Isolates of other strains were included in this study and are listed.

b Symptoms were observed in the infected host.

c Intercepted as budwood.

d No published paper identified. 
Recombination analysis. Three separate strain-focused recombination analyses were performed using the Recombination Detection Program, RDP versions 4.13 and 4.43 (Martin et al. 2010). Analyses were carried out on sets of full genome PPV sequences, using the default parameters for RDP (Martin and Rybicki, 2000), GENECONV (Padidam et al. 1999), Chimaera (Posada and Crandall, 2001), MaxChi (Maynard Smith 1992), BOOTSCAN (Martin et al. 2005), and SISCAN (Gibbs et al. 2000). To identify potential hotspots of recombination, recombination results from all 14 available full-genome PPV W sequences were subjected to breakpoint distribution analysis in the RDP4.43 suite.

In silico simulation of recombinants and analysis. Preliminary analysis revealed no intrastrain recombination events among D strain isolates. An approximate "distance threshold" (below which recombination events are likely undetectable with current methods) can be calculated using $Y=[2 \ln (4 x)] / L$, where $Y$ is the distance threshold, $x$ is the number of sequences in the data set, and $L$ is the length of the alignment (Martin et al. 2010). Comparing this number to pairwise distance comparisons of the 64 PPV D sequences in this dataset suggests that if intrastrain recombination had occurred among D isolates, RDP4 should detect at least some evidence of it in the majority of instances. To test this hypothesis, artificial PPV D recombinants were created in silico between isolate pair Ak1 and Ou6 (low pairwise distance; $2.7 \times 10^{-3}$ ), and between isolate pair Fantasia and Od5 (higher pairwise distance; $1.1 \times 10^{-2}$ ), using MEGA version 5.2. Specifically, a segment of Ou6 and Od5 (nucleotides 3000 to 4200) was arbitrarily chosen and replaced with the corresponding sequence from the other member of that pair. To simulate the passage of evolutionary time, varying amounts of random mutations were introduced $(0,50$, and 100 mutations) using the "mutate DNA" window (www.bioinformatics.org).

\section{RESULTS}

Genome assembly and characterization. The genomes of nine new PPV W isolates (Table 1) were sequenced and then assembled using overlapping virus-derived cDNA clones. Every region of each genome was covered by at least three independently derived and overlapping clones, sequenced bidirectionally. In some cases, five to seven clones were used to resolve ambiguities and obtain a consensus. In all cases cDNA products of approximately 500 to $1,000 \mathrm{bp}$ were used for assembly. Oligonucleotide primers amplifying products that span recombination sites were used in some cases to confirm the existence of recombination events. The genomes of the nine new PPV W isolates sequenced in this study varied from 9,786 to 9,789 nucleotides, similar in size to the genomes of other PPV W accessions deposited in GenBank (Table 1). The variable sizes reflect a nucleotide triplet deletion (deduced valine/isoleucine amino acid deletion) in some isolates, immediately upstream of the DAG motif. The aphid transmissionassociated DAG motif (Shukla et al. 1991) is present in all PPV W isolates with complete sequences available. In pairwise comparisons, the identities of the genomes ranged from 92 to $99.9 \%$ and 96.2 to $99.9 \%$ for the nucleotide and amino acid sequences, respectively. The divergence values are shown below the diagonal line in Supplementary Table S2. The nucleotide sequence of the PIPO region of the PPV W genomes is the most conserved coding region with identities of 96.2 to $98.1 \%$ when compared with the putative archetypal isolate LV-141pl. To compare W strain sequence similarities on a per-gene and whole genome basis, an "archetypal W" was selected as a reference isolate, by using the program Ancestor v.1.1 (Diallo et al. 2010) with a W strain Newick format tree rooted at the midpoint. $\mathrm{LV}-141 \mathrm{pl}$ was identified as a putative archetypal isolate and this was supported further using the program MaxAlike (Menzel et al. 2011); all supporting the selection of LV-141pl. Distance measurements and percent similarities/ differences were calculated using MEGA version 5.2 (Tamura et al. 2011). The deduced amino acid sequences of the $6 \mathrm{~K} 1$ and
NIa/Pro proteins are the most conserved proteins. The P1 coding region and deduced protein is the most variable or least conserved region of the coding regions among PPV $\mathrm{W}$ isolates with percent identities compared with LV-141pl of 86.7 to $94 \%$ and 89.3 to $94.8 \%$, for the nucleotide and amino acid sequences, respectively.

In addition to the DAG motif at the $\mathrm{N}$-terminus of the $\mathrm{CP}$ protein, all PPV W isolates contain the conserved tetra-peptide KITC (Urcuqui-Inchima et al. 2001) and the PTK motif (Peng et al. 1998) associated with aphid transmission found within the HC-Pro region of the genome. The autoproteolytic cleavage site at the C-terminus of the HC-Pro polypeptide of all $\mathrm{W}$ isolates is consistent with the conserved motif described by Carrington and Herndon (1992), with tyrosine, valine, glycine, and glycine residues at positions $-4,-2,-1$, and +1 , respectively. Interestingly, the -5 position is quite variable among $\mathrm{W}$ isolates with alanine, threonine, methionine, or lysine in that position. The cleavage site at the $\mathrm{C}$-terminus of the $6 \mathrm{~K} 1$ protein is conserved among all $\mathrm{W}$ isolates with sequence as described by James and Varga (2005). Comparisons of the amino acid residues of the NIa/Pro recognition and cleavage site of the strain $\mathrm{C}$ isolate of BY101-2 (Calvo et al. 2014) with the corresponding region of the PPV W isolates showed that the residues were conserved across the isolates of both strains except for $\mathrm{Q}$ to $\mathrm{H}$ and $\mathrm{I}$ to $\mathrm{V}$ substitutions at the $\mathrm{N}$ - and $\mathrm{C}$-terminus, respectively. The histidine at the $\mathrm{N}$-terminus is conserved among all PPV W isolates, but unique to this strain. The cleavage site $\mathrm{Q} / \mathrm{S}$ is conserved and is identical for all $\mathrm{W}$ isolates. The recognition site at the $\mathrm{C}$-terminus of the NIa protein of all PPV W isolates has conserved residues at positions $-6,-4,-3,-2,-1$, and +1 . In the case of the cleavage site at the $\mathrm{NIb} / \mathrm{CP}$ junction, two forms are represented among W isolates: NIVMHQ/A, unique to $\mathrm{W}$ isolates; and NIVVHQ/A, associated with C strain isolates (James and Varga 2005). PPV W isolate $1410-1$ has a valine at the +1 position, the only $\mathrm{W}$ isolate analyzed to date with that amino acid substitution.

There appear to be differences in the host range of certain PPV W isolates. Prunus tomentosa (downy cherry) is a host for $\mathrm{W}$ isolate RD4 (Sheveleva et al. 2012b), but not a host for W isolate UKR 44189 (Mavrodieva et al. 2013). Carbonell et al. (2013) identified amino acid residues at specific positions at the $\mathrm{N}$-terminus of the $\mathrm{CP}$ of PPV that influence host adaptation. The region identified by Carbonell et al. (2013) can be defined as the putative motif DxxK/ $\mathrm{RxT} / \mathrm{I} / \mathrm{A} / \mathrm{VxV} / \mathrm{T} / \mathrm{AT} / \mathrm{A} / \mathrm{I}$. PPV W isolate RD4 has DxxKxAxPA at this location while isolate UKR 44189 has DxxRxAxPA, with the lysine in isolate RD4 replaced by arginine in isolate UKR 44189. It is interesting to note that isolates of the PPV strains ( $\mathrm{C}$ and $\mathrm{CR}$ ) known to infect cherry naturally both have the unique motif DxxKxTxTT in this position.

Phylogenetic relationships. Phylogenetic analyses (Larkin et al. 2007; Perrière and Gouy 1996; Saitou and Nei 1987) were conducted on different regions of the genome of $\mathrm{W}$ isolates, including the NIb, PIPO, and CP coding regions. The relationships were supported by significant bootstrap values. Inconsistencies in tree topologies were observed. These inconsistencies are often evidence of recombination (Chare and Holmes 2006; Myrta et al. 2006; Salminen 2003). The nucleotide sequences of $\mathrm{W}$ isolates with complete genomes sequences available, along with representatives from other PPV strains with more than one complete genome sequence available, were used also in unrooted Neighbor-Net analysis using the SplitsTree4 program developed by Huson and Bryant (2006) and phylogenetic analysis shown in Figure 1A and B, respectively. The network structure shown in Figure 1A illustrates the recombinant nature of PPV Rec isolates. It also shows that isolates of PPV $\mathrm{W}$ are linked together by a network of multiple pathways, suggestive of multiple recombination events. Strain W appears to be a product of recombination. The phylogenetic tree based on complete nucleotide sequences (Fig. 1B) shows the close relationship of isolates of PPV strain $\mathrm{W}$ to isolates of strains $\mathrm{C}$ and $\mathrm{CR}$, supported by high bootstrap values. Figure $1 \mathrm{~A}$ and $\mathrm{B}$ indicate that these three strains share a common ancestor(s). There was no correlation of clustering with host or geographic origin. Phylogenetic 
relationships based on complete genomes indicate that PPV evolved as two major branches or groups from a common ancestor, supported by high bootstrap values, with the groups identified in Figure $1 \mathrm{~B}$ as the alpha group (consisting of M, D, Rec, and EA strains) and the beta group (consisting of $\mathrm{W}, \mathrm{CR}$, and $\mathrm{C}$ strains).
Intrastrain recombination among PPV W isolates. Recombination analysis of the PPV $\mathrm{W}$ isolates sequenced in this study revealed that at least three isolates are clear products of intrastrain recombination (Fig. 2). The associated events are identified as events one to five and are scattered across the genome (Fig. 2,

A

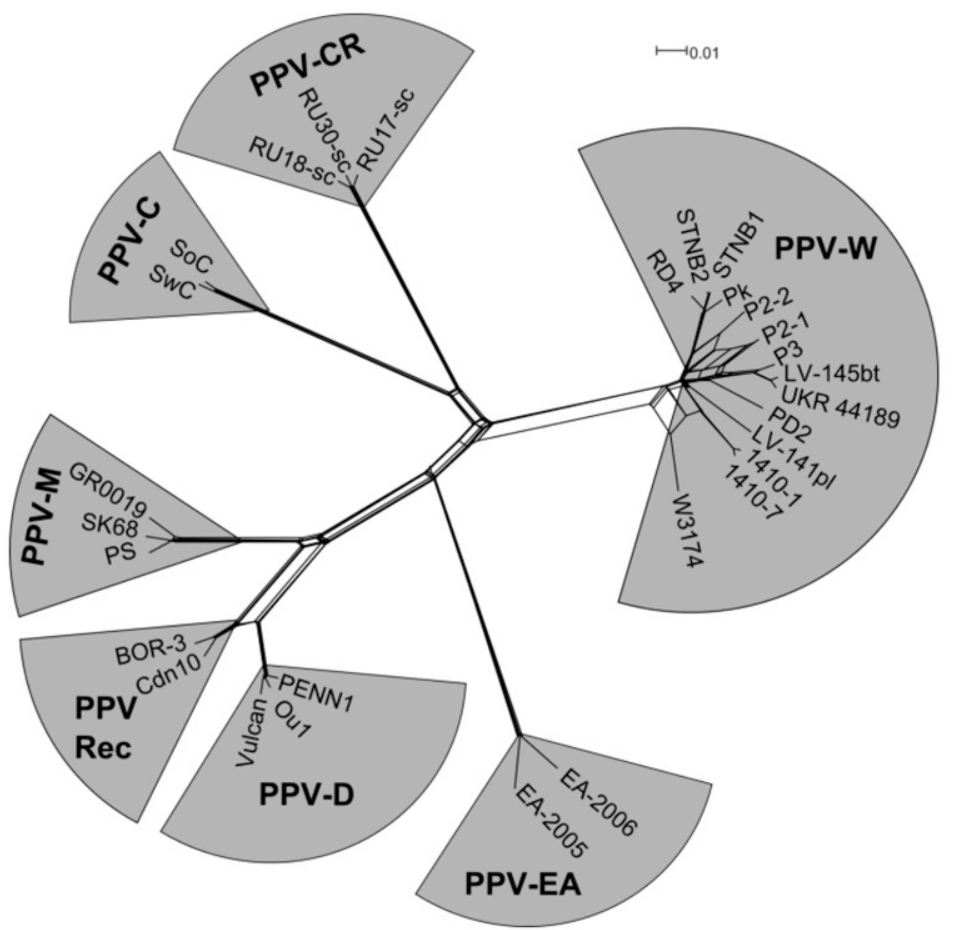

B

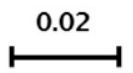
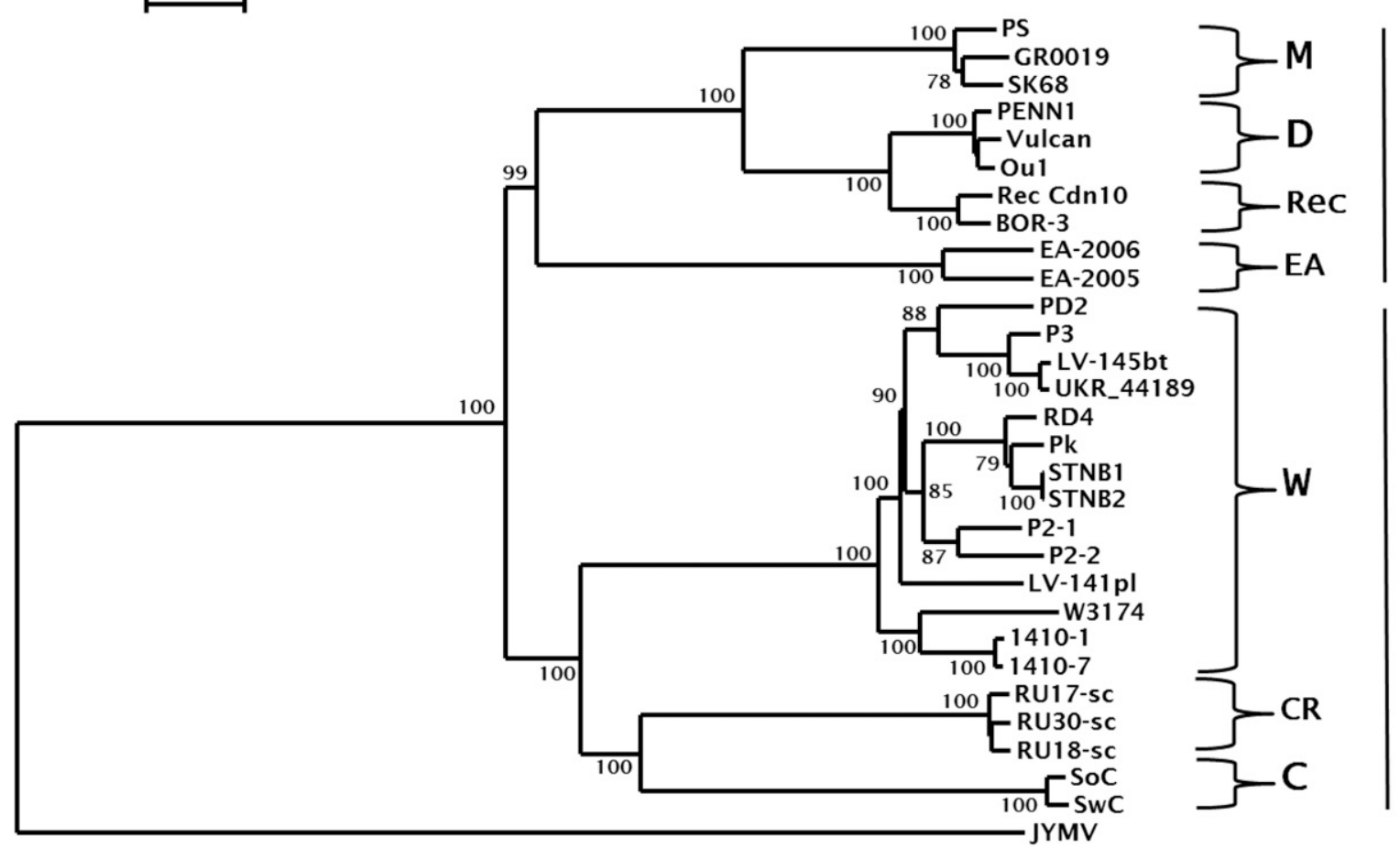

Alpha

Beta

Fig. 1. A, Neighbor-net analysis and B, neighbor-joining phylogenetic analysis of the nucleotide sequences of 29 isolates of Plum pox virus (PPV), with complete genomes available, including 14 isolates of PPV W (five accessions retrieved from GenBank, and nine isolates sequenced in this study), and representative isolates of other PPV strains with at least two full genome sequences available (strains D, M, EA, C, CR, and Rec). The sequences were aligned using CLUSTAL X (Thompson et al. 1997). Neighbor-net analysis was carried out using Splitstree 4.13 (Huson and Bryant 2006), and using default parameters (uncorrected $P$ ). Phylogenetic analysis was carried out using the neighbor-joining method described by Saitou and Nei (1987), with the potyvirus Japanese yam mosaic virus (JYMV) used as an outgroup. The neighbor-joining tree was created with 1,000 replicates and bootstrap values are displayed as percentages, with only values over $70 \%$ displayed at the nodes. The scale bar indicates the number of substitutions per residue. Accession numbers of isolates included in the analyses are given in Table 1 . 
Table 2). All intrastrain recombination events are well supported, and in every case but one (event 5 associated with P2-1) were recognized by the six recombination detection methods used in RDP4 (Table 2). Known interstrain recombinants W isolate W3174 and Rec isolate Cdn10 were included in the analyses for comparison (Table 2). The breakpoint for Rec isolate Cdn10 was identified as nucleotide 8443 (Table 2, Fig. 3). This breakpoint (nucleotide 8443) was confirmed subsequently by RDP4 analysis of a greater data set of 109 PPV isolates, with representatives from the different eligible strains and including nine isolates of the Rec strain. The 8433 breakpoint is in the middle of a conserved region (Fig. 3, boxed) and the fourth of a set of $\mathrm{C}$ nucleotides. Interestingly, this is one set of a series of nucleotide repeats between nucleotides 4379 and 8443 (Fig. 3). Isolate P2-1 is a mosaic isolate with three well supported recombination events indicated. The interstrain recombinant isolate W3174 has a mosaic structure also, with a strain W isolate as the major parent but with minor parents that include both strains $\mathrm{M}$ and $\mathrm{D}$ (Fig. 2, Table 2). In determining breakpoint distribution among PPV W isolates to identify hotspots, 1,000 permutations were performed, with isolate $\mathrm{LV}-141 \mathrm{pl}$ as the type sequence. No specific regions qualified as global hotspots for recombination, but four regions located at nucleotide positions 76 to 290 (A), 574
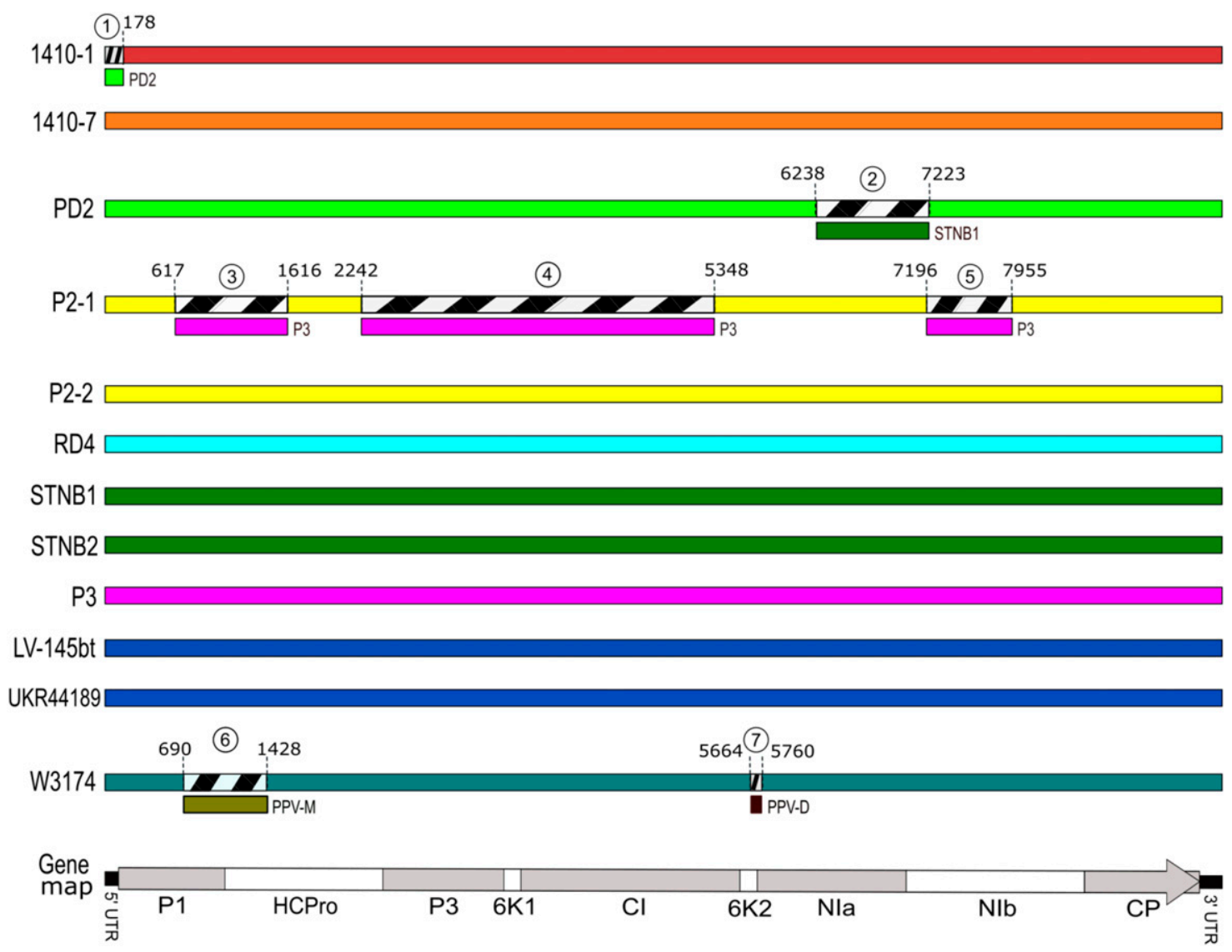

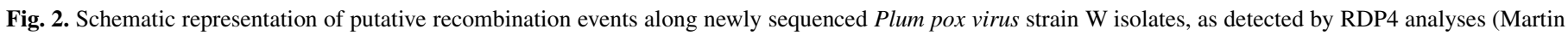

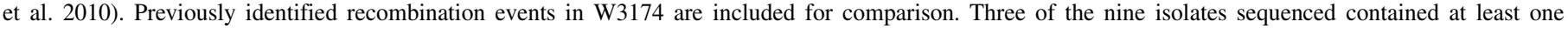

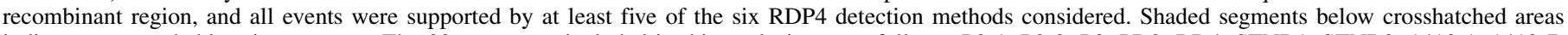

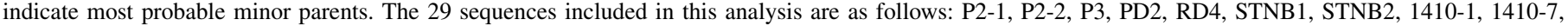

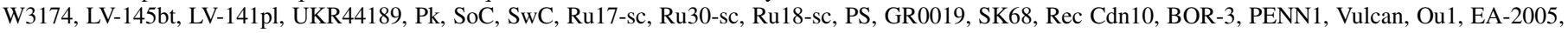
and EA-2006 (Table 1 provides accession numbers).

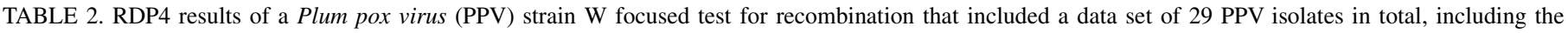
14 PPV W isolates with complete genomes ${ }^{\mathrm{a}}$

\begin{tabular}{|c|c|c|c|c|c|c|c|c|c|c|c|}
\hline \multirow{3}{*}{$\begin{array}{l}\text { Event } \\
\text { number }\end{array}$} & \multicolumn{3}{|c|}{ Sequence designations } & \multicolumn{2}{|c|}{$\begin{array}{c}\text { Detected } \\
\text { breakpoints }\end{array}$} & \multirow{2}{*}{\multicolumn{6}{|c|}{ RDP4 score result for six tests to detect recombination ( $P$ value) }} \\
\hline & Detected & Major & Minor & Start & End & & & & & & \\
\hline & recombinant & parent & parent & position & position & RDP & Geneconv & Bootscan & Maxchi & Chimaera & SiScan \\
\hline 1 & $1410-1$ & $1410-7$ & PD2 & $5^{\prime}$ end & 178 & $1.98 \times 10^{-21}$ & $3.59 \times 10^{-20}$ & $1.95 \times 10^{-21}$ & $9.11 \times 10^{-03}$ & $1.20 \times 10^{-04}$ & $4.26 \times 10^{-06}$ \\
\hline 2 & PD2 & P3 & STNB1 & 6238 & 7223 & $2,42 \times 10^{-22}$ & $5.08 \times 10^{-24}$ & $2.28 \times 10^{-27}$ & $1.83 \times 10^{-10}$ & $7.47 \times 10^{-06}$ & $1.74 \times 10^{-15}$ \\
\hline 3 & P2-1 & P2-2 & P3 & 617 & 1616 & $8.80 \times 210^{-29}$ & $1.34 \times 10^{-26}$ & $8.76 \times 10^{-29}$ & $2.82 \times 10^{-15}$ & $4.31 \times 10^{-15}$ & $8.28 \times 10^{-14}$ \\
\hline 4 & P2-1 & P2-2 & P3 & 2242 & 5348 & $7.56 \times 10^{-38}$ & $9.16 \times 10^{-33}$ & $3.10 \times 10^{-34}$ & $1.44 \times 10^{-23}$ & $5.88 \times 10^{-23}$ & $7.91 \times 10^{-30}$ \\
\hline 5 & P2-1 & P2-2 & P3 & 7196 & 7955 & nd & $7.16 \times 10^{-28}$ & $8.29 \times 10^{-31}$ & $5.11 \times 10^{-12}$ & $2.67 \times 10^{-11}$ & $1.25 \times 10^{-11}$ \\
\hline $6^{*}$ & W3174 & $1410-7$ & PPV M & 690 & 1428 & $9.80 \times 10^{-127}$ & $2.19 \times 10^{-123}$ & $4.55 \times 10^{-127}$ & $7.08 \times 10^{-26}$ & $1.62 \times 10^{-27}$ & $3.30 \times 10^{-28}$ \\
\hline $7 *$ & W3174 & $1410-1$ & PPV D & 5664 & 5760 & $2.32 \times 10^{-19}$ & $5.34 \times 10^{-18}$ & $1.70 \times 10^{-17}$ & $6.95 \times 10^{-03}$ & $3.11 \times 10^{-03}$ & nd \\
\hline $8 *$ & Rec Cdn 10 & PPV D & PPV M & 8443 & $3^{\prime}$ end & $7.76 \times 10^{-58}$ & $5.83 \times 10^{-45}$ & $2.05 \times 10^{-57}$ & $3.25 \times 10^{-22}$ & $6.27 \times 10^{-23}$ & $2.97 \times 10^{-25}$ \\
\hline
\end{tabular}

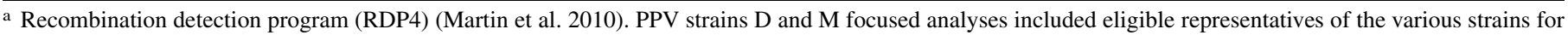
a total of 109 isolates. The $\mathrm{C}$ strain focused analysis included five strain $\mathrm{C}$ isolates with complete sequences and representatives of other strains for a total of 15 isolates. * indicates previously characterized. nd = not detected using RDP4.43. 
to 727 (B), 1510 to 1581 (C), and 7121 to 7314 (D) exceeded the confidence threshold at the local level, with region A exceeding also the $99 \%$ confidence level. Three regions are located within the 5' two-thirds of the PPV W genome, consistent with the observations of Tan et al. (2004) and Ohshima et al. (2007) in other potyviruses.

Recombination analysis of some isolates of PPV strains other than strain W. Intrastrain recombination among isolates of PPV strain C, and among isolates of PPV strain M were detected (Fig. 4; Table 3, events I and II, respectively). Event I is an intrastrain recombination event at the $3^{\prime}$ terminus of the genome, supported by five of the six tests of the RDP4 program (Table 3). PPV C isolate SoC (AY184478) is identified as a recombinant isolate with SwC (Y09851) as the major parent. Event II (Table 3) is a less supported (only three of six tests) intrastrain recombination event among isolates of strain $\mathrm{M}$ in the region of the $\mathrm{P} 1 \mathrm{C}$-terminus/ HC-Pro N-terminus, suggesting that PPV M isolate VAR-2/551 (HF5815101) is possibly a recombinant (Fig. 4, Table 3). A new interstrain recombinant event (Table 3, event III; Fig. 4) was identified supported by all six of the RDP4 tests indicated in Table 3. PPV M isolate SK-111pl (HF585099) is identified as the product of recombination between M isolate PS (AJ243957), and PPV Rec isolate BOR-3 (AY028309) (Table 3, Fig. 4). The RDP plot shown in Figure 4B further supports and clearly illustrates the interstrain recombination event.

In silico analysis of recombination among PPV D strain isolates. Salminen (2003) indicated that a threshold of genetic diversity is essential to allow the detection of recombination events.

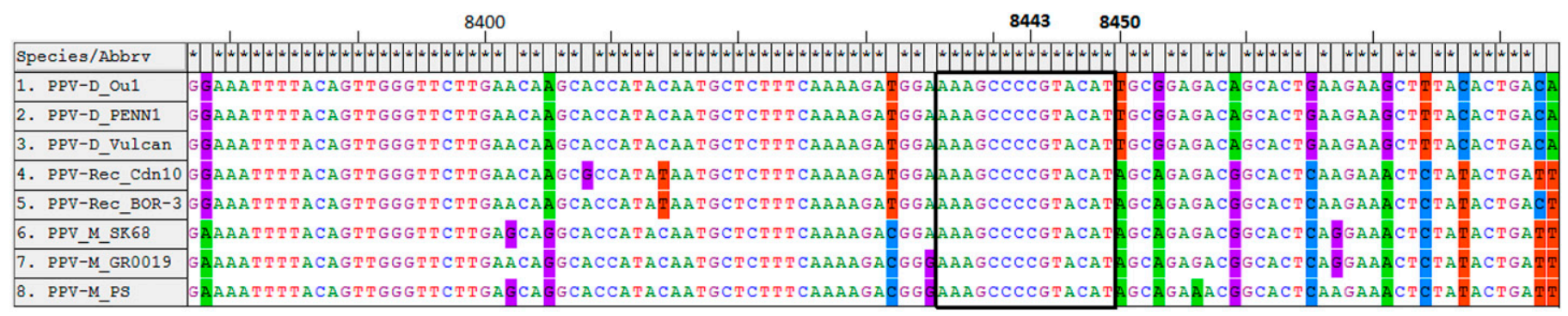

Fig. 3. Illustration of the area surrounding the breakpoint in Plum pox virus (PPV) Rec sequences BOR-3 and Cdn 10 compared with representative sequences from the parent strains D and M. Analysis in RDP4.43 identified the breakpoint at 8443 bp (indicated). Created using MEGA5 (Tamura et al. 2011). The nucleotide at position 8450 identified previously as the breakpoint (Glasa et al. 2004) is indicated, as well as a conserved region upstream of nucleotide 8450 (boxed).

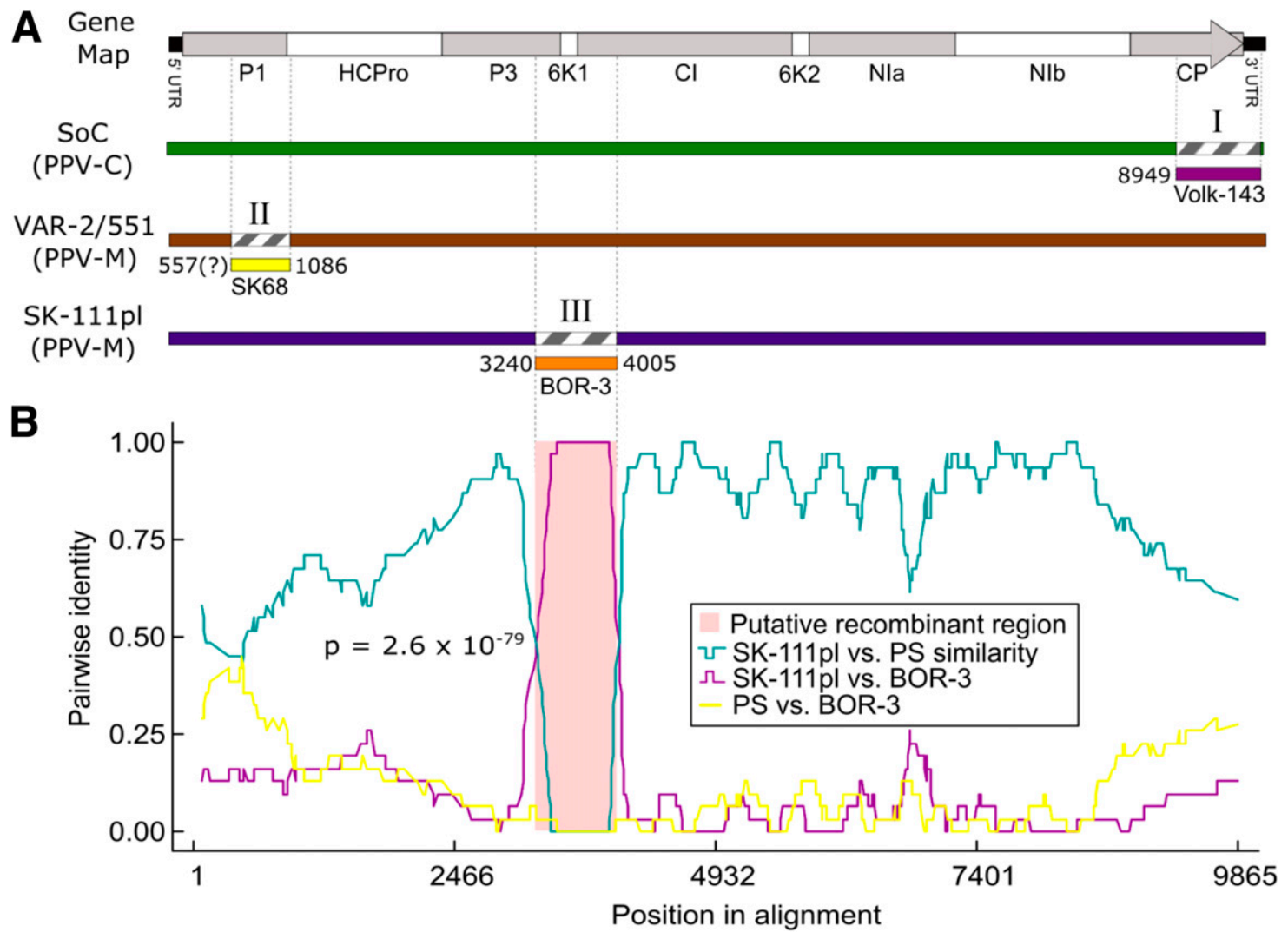

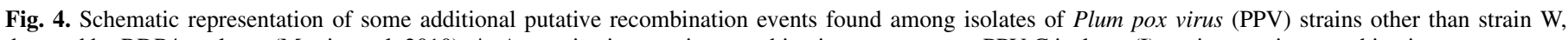

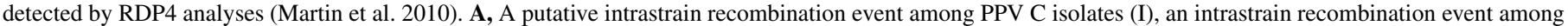

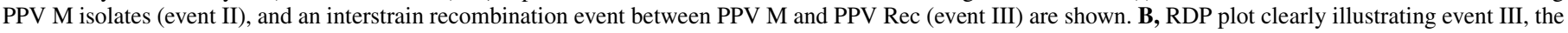

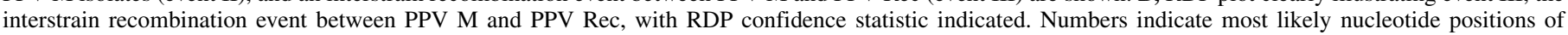

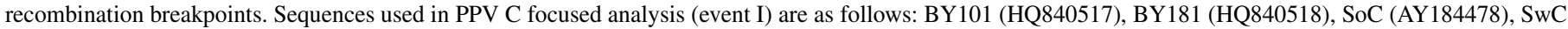

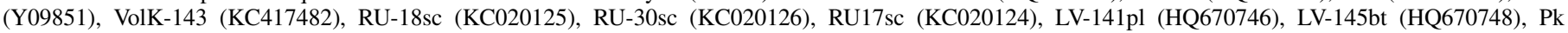

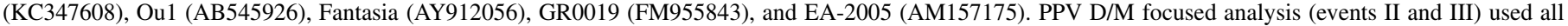
publicly available full PPV genomes. 
PPV strain D is relatively homogeneous, with low levels of diversity among its isolates (Sheveleva et al. 2012a). In this study 64 PPV D isolates were analyzed but no evidence of recombination was detected. Isolate pairs that appear to span the range of diversity detected among D isolates were selected as parents, Japanese isolates Ak1 (AB576045) and Ou6 (AB576062), with pairwise distance $2.7 \times 10^{-3}$; and parents Fantasia (Canadian, AY912056) and Od5 (Japanese, AB576080), with pairwise distance $1.1 \times 10^{-2}$. Artificial random mutations were introduced to simulate events that might occur with evolution, and to allow identification. The four parents of these artificial sequences were removed from the analysis, and the newly constructed isolates used for analysis. The artificial recombination events between the "low" distance pair (AK1 and Ou6) was not detected in any of the cases, and the recombination events between isolates Fantasia and Od5 gave only trace evidence in RDP4, whether zero, 50, or 100 random mutations were introduced. The mean pairwise distances among isolates of real-world strains where recombination events were detected ranged from approximately $5.59 \times 10^{-2}$ with SE $1.2 \times$ $10^{-3}$ (W strain) to $1.33 \times 10^{-2}$ with SE $0.8 \times 10^{-3}$ (C strain) (Table 4). It seems that the pairwise distance values between PPV D isolates are below the threshold for reliable identification of recombination events, with any degree of confidence. This lends support to the notion that detection with confidence of any intrastrain recombination events among PPV D isolates, and other similarly homogeneous strains, may be challenging or improbable.

\section{DISCUSSION}

Recombination events have been described previously in PPV (Cervera et al. 1993; Glasa et al. 2004, 2011; Myrta et al. 2006; Serçe et al. 2009), but in every case these have been interstrain recombination events. This study provides the first definitive evidence of the common occurrence of intrastrain recombination in PPV. This in part is due to the fact that the major strains of PPV consist of isolates that are relatively homogeneous (Glasa et al. 2006; Matic et al. 2011; Sheveleva et al. 2012a). Isolates of PPV strain $\mathrm{W}$ are genetically diverse and clearly exceed the threshold alluded to by Salminen (2003) that is required for the detection of recombinant events. In this study RDP4 analysis and in silico recombination simulation studies indicate that an intrastrain threshold for the detection of recombination events is likely in the range of approximately $0.78 \times 10^{-2}$ to $1.33 \times 10^{-2}$ mean pairwise distance. PPV W isolates exceed this threshold of diversity with a mean pairwise distance of $5.59 \times 10^{-2}$. Isolates of strain $\mathrm{M}$ and $\mathrm{C}$ meet or exceed the threshold for recombination detection as intrastrain recombination events were detected in these strains.

Although no regions of the PPV genome qualified as global hotspots for recombination, there are certainly local regions of the genome that appear more susceptible to recombination events, including the $5^{\prime}$ two-thirds of the genome, consistent with that seen in other potyviruses such as Turnip mosaic virus (TuMV) (Ohshima et al. 2007; Tan et al. 2004). Of the 14 PPV W isolates with complete sequences available, three isolates are the products of intrastrain recombinants, and one isolate (W3174) is an interstrain recombinant, for a total of four or $28.6 \%$ of isolates that are recombinants. Intrastrain recombinants were identified among $\mathrm{M}$ and $\mathrm{C}$ strain isolates for the first time, and a novel recombination event between strain $\mathrm{M}$ and recombinant strain Rec was identified. In describing the mosaic recombinant nature of PPV strain T, Glasa and Candresse (2005) identified a putative recombinant event in the $\mathrm{HC}-\mathrm{Pro} / \mathrm{P} 3$ region of the Ab-Tk isolate. At least four of the eight novel recombination events described in this study were detected between the $\mathrm{P} 1$ region and the $\mathrm{C}$-terminus of the $\mathrm{CI}$ region. Interestingly, the $5^{\prime}$ terminus of PPV (5'UTR to P1 junction) seems to be a region where recombination events are less frequent. A recombination event has been identified for the first time in this region in this study (W isolate 1410-1). Recombination events confined to the $3^{\prime}$ terminus (NIb/CP junction to $3^{\prime} \mathrm{UTR}$ ) are also relatively rare. It is interesting that RDP4 identifies the breakpoint of strain Rec isolates as nucleotide 8443. Using the PHYLPRO method, Glasa et al. (2004) identified the breakpoint as nucleotide 8450 . Nucleotide 8450 clearly represents the sequence transition point from $\mathrm{D}$ to $\mathrm{M}$. Due to the conserved nucleotides upstream of the 8450 transition point, a breakpoint in this area cannot be excluded. RDP4 consistently identified nucleotide 8433 as the breakpoint. In this case, it is indeed possible that there is a breakpoint separate from the strain transition point. In this study, a recombinant event at the $3^{\prime}$ terminus of PPV was detected in the $\mathrm{C}$ strain isolate SoC. In general, recombination events at the $3^{\prime}$ terminus of the PPV genome are rare.

It appears that among species in the genus Potyvirus, recombination events are detected more commonly in the region of the genome extending from the $5^{\prime} \mathrm{UTR} / \mathrm{P} 1$ region to the CI coding region (Desbiez and Lecoq 2008; Ohshima et al. 2007; Tan et al. 2004;

TABLE 3. RDP4 results for additional recombination analyses ${ }^{\mathrm{a}}$

\begin{tabular}{|c|c|c|c|c|c|c|c|c|c|c|c|}
\hline \multirow[b]{3}{*}{ Event } & \multicolumn{3}{|c|}{ Sequence designations } & \multicolumn{2}{|c|}{$\begin{array}{c}\text { Detected } \\
\text { breakpoints }\end{array}$} & \multirow{2}{*}{\multicolumn{6}{|c|}{ RDP4 Score result for six tests to detect recombination ( $P$ value) }} \\
\hline & Detected & Major & Minor & Start & End & & & & & & \\
\hline & recombinant(s) & parent & parent & position & position & RDP & Geneconv & Bootscan & Maxchi & Chimaera & SiScan \\
\hline I & SoC (C) & $\mathrm{SwC}(\mathrm{C})$ & VolK-143* (C) & 8949 & $9755^{*}$ & $1.29 \times 10^{-04}$ & $8.38 \times 10^{-03}$ & $8.16 \times 10^{-03}$ & $5.62 \times 10^{-03}$ & $1.06 \times 10^{-03}$ & $1.13 \times 10^{-03}$ \\
\hline II & Var-2/551 & $\operatorname{Var}-2 / 531(\mathrm{M})$ & SK68 (M) & $557 *$ & 1086 & $8.71 \times 10^{-06}$ & $9.70 \times 10^{-05}$ & $8.76 \times 10^{-06}$ & nd & nd & nd \\
\hline III & SK-111pl (M) & PS (M) & BOR-3 (Rec) & 3240 & 4005 & $2.60 \times 10^{-79}$ & $4.49 \times 10^{-78}$ & $8.78 \times 10^{-80}$ & $8.58 \times 10^{-20}$ & $5.88 \times 10^{-20}$ & $4.61 \times 10^{-24}$ \\
\hline
\end{tabular}

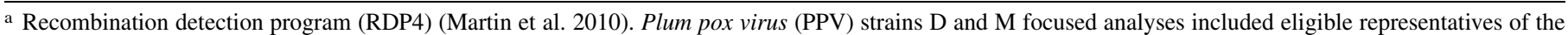
various strains for a total of 109 isolates. The $\mathrm{C}$ strain focused analysis included five strain $\mathrm{C}$ isolates with complete sequences and representatives of other strains for a total of 15 isolates. * indicates presumed (not conclusively determined). nd = not detected.

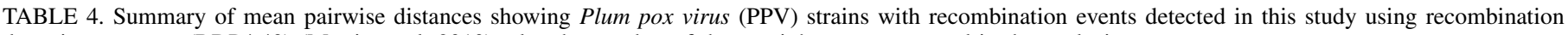
detection program (RDP4.43) (Martin et al. 2010), plus the number of that strain's sequences used in the analysis ${ }^{\mathrm{a}}$

\begin{tabular}{|c|c|c|c|c|c|}
\hline $\begin{array}{l}\text { PPV } \\
\text { strain }\end{array}$ & $\begin{array}{c}\text { Mean pairwise } \\
\text { distance }\end{array}$ & $\begin{array}{l}\text { Standard error in } \\
\text { pairwise distances }\end{array}$ & $\begin{array}{c}\text { Strain of interest } \\
\text { sequences used }\end{array}$ & $\begin{array}{c}\text { Total PPV } \\
\text { sequences used }\end{array}$ & $\begin{array}{c}\text { Novel recombination } \\
\text { events found }\end{array}$ \\
\hline $\mathrm{W}$ & $5.59 \times 10^{-2}$ & $1.2 \times 10^{-3}$ & 14 & 29 & 5 \\
\hline M & $3.01 \times 10^{-2}$ & $0.7 \times 10^{-3}$ & 10 & 109 & 2 \\
\hline $\mathrm{C}$ & $1.33 \times 10^{-2}$ & $0.8 \times 10^{-3}$ & 5 & 15 & 1 \\
\hline $\mathrm{D}$ & $0.78 \times 10^{-2}$ & $0.4 \times 10^{-3}$ & 64 & 109 & 0 \\
\hline
\end{tabular}

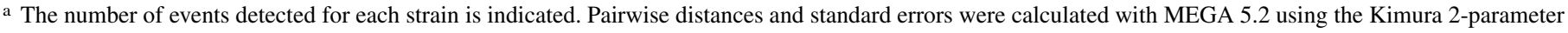
model (Tamura et al. 2011). 
this study). Tan et al. (2004) found that of 18 recombinants detected in a worldwide collection of TuMV isolates, only two were in the $3^{\prime}$ one-third region of the genome. This pattern seems consistent for PPV also, but it is clear that frequency may not be correlated with successful establishment, as the $3^{\prime}$ generated PPV Rec strain isolates are very successful and widely distributed (Glasa et al. 2004). Several different mechanisms have been described for recombination among RNA viruses requiring simultaneous presence of the two contributing viruses or isolates in the same host and in the same cell (Morel et al. 2011). These mechanisms depend on flanking sequences and/or secondary structures (Morel et al. 2011; Nagy et al. 1998; Nagy and Simon 1998). Ohshima et al. (2007) described GC-rich sequences and AU-rich sequences upstream and downstream of the recombination sites, respectively, of the potyvirus TuMV. A similar pattern of nucleotide distribution was not observed with the PPV W recombinant isolates. Members of the genus Potyvirus such as PPV possess amino acid motifs associated with aphid transmissibility. Some of these such as the KITC (Urcuqui-Inchima et al. 2001) and PTK (Peng et al. 1998) are located in the HC-Pro region, while the DAG motif (Shukla et al. $1991)$ is located in the CP region. There are differences in the efficiency of aphid transmissibility between strains (James et al. 2013), and between isolates of the same strain (Schneider et al. 2011). It is possible that there are other factors involved and/or the context of the motifs may help determine efficiency of transmission. It is conceivable therefore that recombination could transform a less efficiently transmitted or nontransmitted isolate into a very efficiently transmitted isolate. Pathogenicity determinants in the PPV genome have been identified from the N-terminus region polyprotein to the C-terminus region (Salvador et al. 2008; Sáenz et al. 2000), and host determinants have been identified in various regions of the PPV genome including the $\mathrm{CP}$ region (Calvo et al. 2014; Carbonell et al. 2013). Chen et al. (2008) identified a single amino acid residue in the NIa-Pro peptide of the potyvirus Papaya ringspot virus that determines host specificity. Calvo et al. (2014) showed that the $\mathrm{C}-\mathrm{P} 3(\mathrm{PIPO}) / 6 \mathrm{~K} 1 / \mathrm{N}-\mathrm{CI}$ region of the virus contain viral determinants that influence symptomatology, viral amplification, and virus movement and that single amino acid changes in this region of the PPV genome can influence host adaptation. This means therefore that recombination in potyviruses such as PPV has the potential to change pathogenicity and host specificity, especially with regions such as the HC-Pro identified as having a high propensity for the occurrence of recombination events.

Recombination as a mechanism driving evolution is likely underestimated for two reasons; (i) it may not be screened for in routine analysis (Morel et al. 2011), and (ii) there is a threshold of genetic diversity among parents that is required for the detection of recombination events (Salminen 2003). This is the first time to our knowledge that a recombinant strain has been identified as a putative parent in a recombination event. This along with the fact that several 'mosaic' recombinants exist indicates clearly that previous recombination events do not preclude subsequent recombinant events. It seems likely that the role of recombination in the evolution of PPV is underestimated since only events between suitably diverse genomes can be identified. Understanding the mechanisms that contribute to PPV evolution is important as the resulting genetic diversity may influence its host range, transmissibility, virulence, detectability, and/or identification. In this study, intrastrain recombination events were detected in PPV strain $\mathrm{W}$ isolates and one case each in strain $\mathrm{C}$ and strain $\mathrm{M}$. If genetic diversity is directly correlated with time of evolutionary origin, it is indeed possible that PPV strain W, with is relatively high genetic diversity (Glasa et al. 2011; Sheveleva et al. 2012a), may represent an ancestral strain of PPV. However, the availability of more sequence data for isolates of all strains of PPV, and better knowledge of the true global distribution of PPV, will allow more accurate determination of evolutionary relationships and country of origin.
PPV evolved into two major branches or groups, identified in this study as alpha and beta.

The role of recombination as a mechanism that drives evolution is not well understood (Ohshima et al. 2007), and understanding its role in plant RNA virus evolution is critical (Chare and Holmes 2006). Understanding the relative frequency of mechanisms that drive genetic changes, such as mutation events (Drake and Holland 1999) and recombination events (Roossinck 1997), will help to resolve these concerns. It will allow more accurate determination of their contribution to the genetic diversity observed, and help in better understanding patterns of evolution in RNA viruses such as PPV. This will facilitate prediction of possible changes, better understanding of the diversity observed and the variability of certain biological traits such as host range, pathogenicity, and transmissibility. These are important factors that influence effective management and control of dangerous and harmful diseases like plum pox/sharka.

\section{ACKNOWLEDGMENTS}

This research was conducted with funding from the Federal Government of Canada under the Plum Pox Monitoring and Management Program (PPMMP) being implemented by the Canadian Food Inspection Agency (CFIA) and Agriculture and Agri-Food Canada (AAFC). This work was supported in part by the Russian Foundation for Basic Research Project 14-04-01786a.

\section{LITERATURE CITED}

Adams, M. J., Zerbini, F. M., French, R., Rabenstein, F., Stenger, D. C., and Valkonen, J. P. T. 2011. Family Potyviridae. Pages 1069-1089 in: Virus Taxonomy, Ninth Report of the International Committee on Taxonomy of Viruses. A. M. Q. King, M. J. Adams, E. B. Carstens, and E. J. Lefkowitz, eds. Elsevier Academic Press, London.

Boscia, D., Zeramdini, H., Cambra, M., Potere, O., Gorris, M. T., Myrta, A., Di Terlizzi, B., and Savino, V. 1997. Production and characterization of a monoclonal antibody specific to the M serotype of plum pox potyvirus. Eur. J. Plant Pathol. 103:477-480.

Calvo, M., Malinowski, T., and Garcia, J. A. 2014. Single amino acid changes in the 6K1-CI region can promote the alternative adaptation of Prunus- and Nicotiana-propagated Plum pox virus $\mathrm{C}$ isolates to either host. Mol. PlantMicrobe Interact. 27:136-149.

Cambra, M., Asensio, M., Gorris, M. T., Pérez, E., Camarasa, E., Garciá, J. A., Moya, J. J., López-Abella, D., Vela, C., and Sanz, A. 1994. Detection of plum pox potyvirus using monoclonal antibodies to structural and nonstructural proteins. EPPO Bull. 24:569-577.

Cambra, M., Capote, N., Myrta, A., and Llácer, G. 2006. Plum pox virus and the estimated costs associated with sharka disease. EPPO Bull. 36: 202-204.

Candresse, T., Cambra, M., Dallot, S., Lanneau, M., Asensio, M., Gorris, M. T., Revers, F., Macquaire, G., Olmos, A., Boscia, D., Quiot, J. B., and Dunez, J. 1998. Comparison of monoclonal antibodies and polymerase chain reaction assays for the typing of isolates belonging to the $\mathrm{M}$ and $\mathrm{D}$ serotypes of plum pox potyvirus. Phytopathology 88:198-204.

Carbonell, A., Maliogka, V. I., de Jesús Pérez, J., Salvador, B., San León, D., García, J. A., and Simón-Mateo, C. 2013. Diverse amino acid changes at specific positions in the N-terminal region of the coat protein allow Plum pox virus to adapt to new hosts. Mol. Plant-Microbe Interact. 26:1211-1224.

Carrington, J. C., and Herndon, K. L. 1992. Characterization of the potyviral HC-Pro autoproteolytic cleavage site. Virology 187:308-315.

Cervera, M. T., Riechmann, J. L., Martín, M. T., and García, J. A. 1993. $3^{\prime}$-Terminal sequence of plum pox virus PS and ŏ6 isolates: evidence of RNA recombination within the potyvirus group. J. Gen. Virol. 74:329-334.

Chare, E. R., and Holmes, E. C. 2006. A phylogenetic survey of recombination frequency in plant RNA viruses. Arch. Virol. 151:933-946.

Chen, K.-C., Chiang, C.-H., Raja, J. A. J., Liu, F.-L., Tai, C.-H., and Yeh, S.-D. 2008. A single amino acid of NIaPro of Papaya ringspot virus determines host specificity for infection of papaya. Mol. Plant-Microbe Interact. 21: 1046-1057.

Desbiez, C., and Lecoq, H. 2008. Evidence of multiple intraspecific recombinants in natural populations of Watermelon mosaic virus (WMV, Potyvirus). Arch. Virol. 153:1749-1754.

Diallo, A. B., Makarenkov, V., and Blanchette, M. 2010. Ancestors 1.0: A web server for ancestral sequence reconstruction. Bioinformatics 26:130-131. 
Drake, J. W., and Holland, J. J. 1999. Mutation rates among RNA viruses. Proc. Natl. Acad. Sci. USA 96:13910-13913.

Fanigliulo, A., Comes, S., Maiss, E., Piazzolla, P., and Crescenzi, A. 2003. The complete nucleotide sequence of Plum pox virus isolates from sweet (PPVSwC) and sour (PPV-SoC) cherry and their taxonomic relationships within the species. Arch. Virol. 148:2137-2153.

García, J. A., Glasa, M., Cambra, M., and Candresse, T. 2014. Plum pox virus and sharka: A model potyvirus and a major disease. Mol. Plant Pathol. 15: 226-241.

García, J. A., Riechmann, J. L., Martín, M. T., Guo, H., Simon, L., Fernández, A., Domínguez, E., and Cervera, M. T. 1994. Molecular characterization of plum pox potyvirus. EPPO Bull. 24:543-553.

García-Arenal, F., Fraile, A., and Malpica, J. M. 2001. Variability and genetic structure of plant virus populations. Annu. Rev. Phytopathol. 39:157-186.

Gibbs, M. J., Armstrong, J. S., and Gibbs, A. J. 2000. Sister-scanning: A Monte Carlo procedure for assessing signals in recombinant sequences. Bioinformatics 16:573-582.

Glasa, M., and Candresse, T. 2005. Partial sequence analysis of an atypical Turkish isolate provides further information on the evolutionary history of Plum pox virus (PPV). Virus Res. 108:199-206.

Glasa, M., Malinowski, T., Predajňa, L., Pupola, N., Dekena, D., Michalczuk, L., and Candresse, T. 2011. Sequence variability, recombination analysis, and specific detection of the W strain of Plum pox virus. Phytopathology 101: 980-985.

Glasa, M., Palkovics, L., Komínek, P., Labonne, G., Pittnerová, S., Kúdela, O., Candresse, T., and Šubr, Z. 2004. Geographically and temporally distant natural recombination isolates of Plum pox virus are genetically very similar and form a unique PPV subgroup. J. Gen. Virol. 85:2671-2681.

Glasa, M., Prihodko, Y., Predajňa, L., Nagyová, A., Shneyder, Y., Zhivaeva, T., Šubr, Z., Cambra, M., and Candresse, T. 2013. Characterization of sour cherry isolates of Plum pox virus from the Volga Basin in Russia reveals a new cherry strain of the virus. Virology 103:972-979.

Glasa, M., Svanella, L., and Candresse, T. 2006. The complete nucleotide sequence of the Plum pox virus El Amar isolate. Arch. Virol. 151: 1679-1682.

Hammond, J., Pühringer, H., Da Câmara Machado, A., and Laimer Da Câmara Machado, M. 1998. A broad spectrum PCR assay combined with RFLP analysis for detection and differentiation of Plum pox virus isolates. Acta Hortic. 472:483-490.

Huson, D. H., and Bryant, D. 2006. Application of phylogenetic networks in evolutionary studies. Mol. Biol. Evol. 23:254-267.

James, D., and Varga, A. 2005. Nucleotide sequence analysis of Plum pox virus isolate W3174: Evidence of a new strain. Virus Res. 110:143-150.

James, D., and Varga, A. 2011. Genetic diversity of Canadian isolates of Plum pox virus and its significance. Acta Hortic. 899:29-38.

James, D., Varga, A., and Sanderson, D. 2013. Genetic diversity of Plum pox virus: Strains, disease and related challenges for control. Can. J. Plant Pathol. 35:431-441.

Korboukh, V. K., Lee, C. A., Acevedo, A., Vignizzi, M., Xiao, Y., Arnold, J. J., Hemperly, S., Graci, J. D., August, A., Andino, R., and Cameron, C. E. 2014. RNA virus population diversity, an optimum for maximal fitness and virulence. J. Biol. Chem. 289:29531-29544.

Larkin, M. A., Blackshields, G., Brown, N. P., Chenna, R., McGettigan, P. A., McWilliam, H., Valentin, F., Wallace, I. M., Wilm, A., Lopez, R., Thompson, J. D., Gibson, T. J., and Higgins, D. G. 2007. ClustalW and ClustalX version 2. Bioinformatics 23:2947-2948.

Maejima, K., Himeno, M., Komatsu, K., Takinami, Y., Hashimoto, M., Takahashi, S., Yamaji, Y., Oshima, K., and Namba, S. 2011. Molecular epidemiology of Plum pox virus in Japan. Phytopathology 101:567-574.

Martin, D. P., Lemey, P., Lott, M., Moulton, V., Posada, D., and Lefeuvre, P. 2010. RDP3: A flexible and fast computer program for analyzing recombination. Bioinformatics 26:2462-2463.

Martin, D. P., Posada, D., Crandall, K. A., and Williamson, C. 2005. A modified bootscan algorithm for automated identification of recombinant sequences and recombination breakpoints. AIDS Res. Hum. Retroviruses 21:98-102.

Martin, D. P., and Rybicki, E. 2000. RDP: Detection of recombination amongst aligned sequences. Bioinformatics 16:562-563.

Matic, S., Elmaghraby, I., Law, V., Varga, A., Reed, C., Myrta, A., and James, D. 2011. Serological and molecular characterization of isolates of Plum pox virus strain El Amar to better understand its diversity, evolution, and unique geographic distribution. J. Plant Pathol. 93:303-310.

Mavrodieva, V., James, D., Williams, K., Negi, S., Varga, A., Mock, R., and Levy, L. 2013. Molecular analysis of a Plum pox virus $\mathrm{W}$ isolate in plum germplasm hand carried into the USA from the Ukraine shows a close relationship to a Latvian isolate. Plant Dis. 97:44-52.

Maynard Smith, J. 1992. Analyzing the mosaic structure of genes. J. Mol. Evol. 34:126-129.
Menzel, P., Stadler, P. F., and Gorodkin, J. 2011. MaxAlike: Maximum likelihood-based sequence reconstruction with application to improved primer design for unknown sequences. Bioinformatics 27:317-325.

Morel, V., Fournier, C., François, C., Brochot, E., Helle, F., Duverlie, G., and Castelain, S. 2011. Genetic recombination of the hepatitis $\mathrm{C}$ virus: Clinical implications. J. Viral Hepat. 18:77-83.

Myrta, A., Boscia, D., Potere, O., Kölber, M., Németh, M., Di Terlizzi, B., Cambra, M., and Savino, V. 2001. Existence of two serological subclusters of Plum pox virus, strain M. Eur. J. Plant Pathol. 107:845-848.

Myrta, A., Varga, A., and James, D. 2006. The complete genome sequence of an El Amar isolate of Plum pox virus (PPV) and its phylogenetic relationship to other PPV strains. Arch. Virol. 151:1189-1198.

Nagy, P., and Simon, A. 1998. In vitro characterization of late steps of RNA recombination in turnip crinkle virus: I. Role of motif1-hairpin structure. Virol. 249:379-392.

Nagy, P., Zhang, C., and Simon, A. 1998. Dissecting RNA recombination in vitro: Role of RNA sequences and the viral replicase. EMBO J. 17: 2392-2403.

Ohshima, K., Tomitaka, Y., Wood, J. T., Minematsu, Y., Kajiyama, H., Tomimura, K., and Gibbs, A. J. 2007. Patterns of recombination in Turnip mosaic virus genomic sequences indicate hotspots of recombination. J. Gen. Virol. 88:298-315

Padidam, M., Sawyer, S., and Fauquet, C. M. 1999. Possible emergence of new geminiviruses by frequent recombination. Virology 265:218-225.

Palkovics, L., Burgyán, J., and Balázs, E. 1993. Comparative sequence analysis of four complete primary structures of Plum pox virus strains. Virus Genes 7:339-347.

Peng, Y. H., Kadoury, D., Gal-On, A., Huet, H., Wang, Y., and Raccah, B. 1998. Mutations in the HC-Pro gene of zucchini yellow mosaic potyvirus: Effects on aphid transmission and binding to purified virions. J. Gen. Virol. 79:897-904.

Perrière, G., and Gouy, M. 1996. WWW-Query: An on-line retrieval system for biological sequence banks. Biochimie 78:364-369.

Posada, D., and Crandall, K. A. 2001. Evaluation of methods for detecting recombination from DNA sequences: Computer simulations. Proc. Natl. Acad. Sci. USA 98:13757-13762.

Roossinck, M. L. 1997. Mechanism of plant-virus evolution. Annu. Rev. Phytopathol. 35:191-209.

Roossinck, M. L. 2003. Plant RNA virus evolution. Curr. Opin. Microbiol. 6: 406-409.

Sáenz, P., Cervera, M. T., Dallot, S., Quiot, L., Quiot, J.-B., Riechmann, J. L., and García, J. A. 2000. Identification of a pathogenicity determinant of Plum pox virus in the sequence encoding the C-terminal region of protein P3+6K 1 . J. Gen. Virol. 81:557-566.

Saitou, N., and Nei, M. 1987. The neighbour-joining method: A new method for reconstructing phylogenetic trees. Mol. Biol. Evol. 4:406-425.

Salminen, M. 2003. Detecting recombination in viral sequences. Pages 348-377 in: The Phylogenetic Handbook: A Practical Approach to DNA and Protein Phylogeny. M. Salemi and A. M. Vandamme, eds. University Press, Cambridge, UK.

Salvador, B., Delgadillo, M. O., Sáenz, P., García, J. A., and Simón-Mateo, C. 2008. Identification of Plum pox virus pathogenicity determinants in herbaceous and woody hosts. MPMI 21:20-29.

Schneider, W. L., Damsteegt, V. D., Gildow, F. E., Stone, A. L., Sherman, D. J., Levy, L. E., Mavrodieva, V., Richwine, N., Welliver, R., and Luster, D. G. 2011. Molecular, ultrastructural, and biological characterization of Pennsylvania isolates of Plum pox virus. Phytopathology 101:627-636

Scholthof, K.-B., Adkins, S., Czosnek, H., Palukaitis, P., Jacquot, E., Hohn, T., Hohn, B., Saunders, K., Candresse, T., Ahlquist, P., Hemenway, C., and Foster, G. D. 2011. Top 10 plant viruses in molecular plant pathology. Mol. Plant Pathol. 12:938-954.

Serçe, C. U., Candresse, T., Svanella-Dumas, L., Krizbai, L., Gazel, M., and Çăglayan, K. 2009. Further characterization of a new recombinant group of Plum pox virus isolates, PPV-T, found in orchards in the Ankara province of Turkey. Virus Res. 142:121-126.

Sheveleva, A., Ivanov, P., Chirkov, S., Prihodko, Y., Varga, A., and James, D. 2012a. Plum pox virus $\mathrm{W}$ appears to be the most variable strain of the seven recognized strains of the virus. Petria 22:226-232.

Sheveleva, A., Ivanov, P., Prihodko, Y., James, D., and Chirkov, S. 2012b. Occurrence and genetic diversity of Winona-like Plum pox virus isolates in Russia. Plant Dis. 96:1135-1142.

Sheveleva, A., Kudryavtseva, A., Speranskaya, A., Belenikin, M., Melnikova, N., and Chirkov, S. 2013. Complete genome sequence of a novel Plum pox virus strain $\mathrm{W}$ isolate determined by 454 pyrosequencing. Virus Genes 47 : 385-388.

Shukla, D. D., Frenkel, M. J., and Ward, C. W. 1991. Structure and function of the potyvirus genome with special reference to the coat protein coding region. Can. J. Plant Pathol. 13:178-191. 
Szemes, M., Kálmán, M., Myrta, A., Boscia, D., Németh, M., Kölber, M., and Dorgai, L. 2001. Integrated RT-PCR/nested PCR diagnosis for differentiating between subgroups of Plum pox virus. J. Virol. Methods 92:165-175.

Tamura, K., Peterson, D., Peterson, N., Stecher, G., Nei, M., and Kumar, S. 2011. MEGA5: Molecular evolutionary genetics analysis using maximum likelihood, evolutionary distance, and maximum parsimony methods. Mol. Biol. Evol. 28:2731-2739.

Tan, Z., Wada, Y., Chen, J., and Ohshima, K. 2004. Inter- and intralineage recombinants are common in natural populations of Turnip mosaic virus. J. Gen. Virol. 85:2683-2696.

Theilmann, J., Yang, L., and Rochon, D. 2006. Sequence analysis of isolates of the Canadian Plum pox virus, and comparisons to isolates from Europe and the United States. Can. J. Plant Pathol. 28:144-151.

Thompson, J. D., Gibson, T. J., Plewniak, F., Jeanmougin, F., and Higgins, D. G. 1997. The Clustal X windows interface: Fexible strategies for multiple sequence alignment aided by quality analysis tools. Nucleic Acids Res. 25:4876-4882.

Tromas, N., and Elena, S. F. 2010. The rate and spectrum of spontaneous mutations in a plant RNA virus. Genetics 185:983-989.

Tromas, N., Zwart, M. P., Poulain, M., and Elena, S. F. 2014. Estimation of the in vivo recombination rate for a plant RNA virus. J. Gen. Virol. 95: 724-732.

Urcuqui-Inchima, S., Haenni, A.-L., and Bernadi, F. 2001. Potyvirus proteins: A wealth of functions. Virus Res. 74:157-175.

Varga, A., and James, D. 2005. Detection and differentiation of Plum pox virus using real-time PCR with SYBR green and melting curve analysis: a rapid method for strain typing. J. Virol. Methods 123:213-220.

Wetzel, T., Candresse, T., Ravelonandro, M., and Dunez, J. 1991. A polymerase chain reaction assay adapted to plum pox potyvirus detection. J. Virol. Methods 33:355-365. 